\title{
THE EFFECT OF VARIOUS LONG-TERM TILLAGE SYSTEMS ON YIELD AND YIELD COMPONENT OF YELLOW AND NARROW-LEAVED LUPIN
}

\author{
Agnieszka FALIGOWSKA, Jerzy SZUKALA \\ Poznan University of Life Sciences, Department of Agronomy, POLAND \\ Corresponding author: faliga@up.poznan.pl
}

Received: 18.12.2014

\begin{abstract}
A field experiment was conducted in the Wielkopolska region (52 $29^{\prime} \mathrm{N}, 16^{\circ} 49^{\prime}$ E, Poland) in Central Europe. The study was conducted over a 3-year period $(2008,2009,2010)$ as a two-factorial desingn with four replications in the randomised plots The first factor consisted of lupin species (S): yellow lupin (YL) and narrow-leaved lupin (BL); the second factor was the adopted soil tillage system (TS): conventional tillage (CT), reduced tillage (RT) and no-tillage (NT). The following tillage systems were applied continuously since 1997 (before 1997 CT was used). YL compared to BL developed significantly higher stems, a greater plant mass, more pods and seeds per plant, but the number of seeds per plant pod and the mass of 1000 seeds were not differentiated between $S$. The seed yields of lupins were very similar and amounted to $1.15 \mathrm{t} \mathrm{ha}^{-1}$ for YL and $1.01 \mathrm{t} \mathrm{ha}^{-1}$ for BL. NT decreased significantly the plant density both lupin species. The seed yields of both lupin species were very similar and there were not significant differences between TS. For this reason both lupin species may be cultivated in simplified soil tillage systems without losses of seed yields.
\end{abstract}

Key words: narrow-leaved lupin, tillage systems, yellow lupin

\section{INTRODUCTION}

The intensive agriculture system in Europe is changing. Sustainable use of agricultural lands to provide optimal plant production is closely related to agricultural practices (Aksakal and Öztaş, 2010). The EU Common Agricultural Policy encourages farmers to practice sustainable crop rotation and it also promotes good, environment-friendly farming practices, while simultaneously it substantially increases the production of plant proteins (Borreani et al., 2007). An excellent source of protein is lupin. Narrow-leaved lupin is an important crop in Poland and Russia (Dracup and Kirby, 1996). As feed for animals, it may be used as seeds and green forage, which can be also turned in silage (Faligowska et al., $2014 a, 2014 b$ ). The use of lupin in animal nutrition may increase profitability of production (McNaughton, 2011). Moreover, forage legumes are widely used as forage crop to improve soil fertility and to increase the yield of subsequent crops in rotation (Gül et al., 2008). The prices of chemical fertilizer increase continuously due to increasing energy cost which restricted their utilization economically (Erkovan et al., 2014).

These changes in European agriculture include also a reduction in the area dedicated to agricultural production, lowering of prices paid to farmers and environmental conservation. To manage within this framework farmers are obliged to adopt tillage systems that reduce the risks of soil erosion and which may reduce production costs, in order to offset the drop in prices (Hernanz et al., 1995). Profitability of production may be improved by the use of no-tillage (Xinhua and Mahdi, 2004). Current tillage systems within Poland may be divided into 2 broad categories: inversion tillage, known as conventional tillage, and noninversion tillage, known more widely as convention tillage with shallow cultivation or direct drilling (Małecka et al., 2012). Conventional tillage practices are one of the many emerging environment agronomic and economic issues that are addressed in contemporary cropping systems (Jug et al., 2011), but over the past few years there has been a growing interest in the potential of reduced tillage (Kordas, 2005). The reduced tillage makes sense only if it leads to lower production costs without sacrificing yield.

The aim of the presented study was to evaluate effects of conventional, reduced and no-tillage on yield and yield components of yellow and narrow-leaved lupin.

\section{MATERIALS AND METHODS}

A field experiment was conducted at the Złotniki Research Station in the Wielkopolska region $\left(52^{\circ} 29^{\prime} \mathrm{N}\right.$, $16^{\circ} 49^{\prime}$ E, Poland) in Central Europe. The study was conducted over a 3-year period (2008, 2009, and 2010) as a two-factorial desingn with four replications in the randomised plots, and with a basic plot area of $288 \mathrm{~m}^{2}(24$ 
$\times 12 \mathrm{~m})$. The first factor consisted of lupin species: yellow lupin and narrow-leaved lupin; the second factor was the adopted soil tillage system: conventional tillage, reduced tillage and no-tillage. The study was conducted as a stationary experiment and at the same location for each year on the grey-brown podsolic soil $(\mathrm{pH}=4.8$ measured in $1 \mathrm{M} \mathrm{KCL} ; 1.3 \%$ organic matter: $50-110 \mathrm{mg} \mathrm{kg}^{-1} \mathrm{P}, 115-$ $195 \mathrm{mg} \mathrm{kg}^{-1} \mathrm{~K}$ ) in 4-crop rotation. Sowing dates depended on soil water conditions. Yellow lupin cultivar Mister (at a rate $130 \mathrm{~kg} \mathrm{ha}^{-1}$ ) and narrow-leaved lupin cultivar Baron (at a rate $150 \mathrm{~kg} \mathrm{ha}^{-1}$ ) were sown in early April for all tillage systems. The sowing depth for all tillage systems was $4 \mathrm{~cm}$ and the row space was $18 \mathrm{~cm}$. In all the tillage systems plots were drilled with a double disk drill (Great Plains, Solid Stand 10' equipped with a fluted coulter for residue cutting, a double disk for seed placement, and a press wheel, $3 \mathrm{~m}$ wide). The following tillage systems were applied continuously since 1997 (before 1997 CT was used). The straw of the preceding crop (winter wheat) was removed from all plots in all the years of the study. After harvest of the previous crop, the CT consisted of tilling with a disk harrow $(2.5 \mathrm{~m}$ wide) to a depth of $8 \mathrm{~cm}$ and fertilization (in August). In the third week of October the autumn ploughing was performed to a depth of $30 \mathrm{~cm}$ with a 3-furrow reversible plough. In the spring, one week before sowing the pre-sowing tillage was performed with a field cultivator, followed by harrowing and rolling to a depth of $8 \mathrm{~cm}$. The RT in August involved the application of glyphosate herbicide ( $3 \mathrm{~L} \mathrm{ha}^{-1}$ ) to control perennial weeds and volunteers as well as fertilization. In the third week of October only a stubble cultivator ( $2.5 \mathrm{~m}$ wide) was used. In the spring, one week before sowing the presowing tillage operation was performed with a field cultivator, followed by harrowing and rolling to a depth of $8 \mathrm{~cm}$. The NT (after the harvest of winter wheat) consisted in the application of glyphosate herbicide $\left(3 \mathrm{~L} \mathrm{ha}^{-1}\right)$ and fertilization (in August). In the spring, the NT involved also the application of glyphosate herbicide $\left(3 \mathrm{~L} \mathrm{ha}^{-1}\right)$ and sowing directly into the stubble of the previous crop. Fertilisation was uniform for all the tillage systems and each experimental year $\left(80 \mathrm{~kg} \mathrm{P} \mathrm{ha}^{-1}, 100 \mathrm{~kg} \mathrm{~K}^{-1}\right)$. Before sowing the seeds were dressed with fungicide containing tiuram and carboxin $\left(350 \mathrm{ml} 100 \mathrm{~kg}^{\text {seeds }}{ }^{-1} 700 \mathrm{ml}\right.$ water $)$. During the growing season the weeds were controlled with herbicide at the rate of $1.5 \mathrm{~L} \mathrm{ha}^{-1}$ (linuron). Ten days before harvest the lupin was desiccated by diquat $(1.5 \mathrm{~L}$ $\left.\mathrm{ha}^{-1}\right)$. Lupins were harvested annually in early August from the plot of $11.49 \mathrm{~m}^{2}(7.6 \times 1.5)$ using a $1.5 \mathrm{~m}$ wide Wintersteiger Classic Plot Combine. Seed yield was recalculated on standardized $15 \%$ seed moisture weight for $\mathrm{t} \mathrm{ha} \mathrm{h}^{-1}$. The following lupin quality parameters were assessed: plant density per square meter before harvest (4 frames with dimensions of $0.25 \mathrm{~m}^{2}$ ), stem height in $\mathrm{cm}$ (measured on 15 randomly collected whole lupin plants several days before harvest), mass of plants in grams (the same 15 plant samples), the number of pods per plant (the same 15 plants), the number of seeds per plant (the same 15 plants), the number of seeds per pod (the same 15 plants) and 1000-seeds weight in grams (seeds collected from the harvested seed mass; $2 \times 500$ seeds were counted and weighed).

The mean air temperatures during the growing season of lupins (April-August) were higher than the 55-year mean, except in June 2009 and May 2010 (Table 1). In general, all the three years were warmer than the longterm average. Total precipitation during the growing season was greater in $2009(368.1 \mathrm{~mm})$ and $2010(433.0$ $\mathrm{mm})$ than the 55 -year mean $(265.8 \mathrm{~mm})$. The precipitation in 2008 was only $230.6 \mathrm{~mm}$. The best weather conditions for the development of lupins were in 2009, when during production of flowers and pods (June-July), while the precipitation were higher than in the other two years.

Table 1. Mean daily air temperatures and total precipitation in the vegetation periods in 2008-2010 and 1951-2006 (from the Agrometeorological Observatory in Złotniki).

\begin{tabular}{|c|c|c|c|c|c|c|}
\hline \multirow{2}{*}{ Years } & \multicolumn{5}{|c|}{ Vegetation period } & \multirow{2}{*}{$\begin{array}{c}\text { Mean of } \\
\text { total }\end{array}$} \\
\hline & April & May & June & July & August & \\
\hline \multicolumn{7}{|c|}{ Mean temperatures $\left({ }^{\circ} \mathrm{C}\right)$} \\
\hline 2008 & 10.0 & 16.2 & 20.6 & 22.2 & 19.7 & 17.74 \\
\hline 2009 & 14.2 & 15.1 & 16.7 & 21.7 & 21.4 & 17.82 \\
\hline 2010 & 10.5 & 12.0 & 19.2 & 23.0 & 19.6 & 16.86 \\
\hline $\begin{array}{l}1951- \\
2006\end{array}$ & 8.5 & 14.2 & 17.4 & 19.1 & 18.4 & 15.52 \\
\hline \multicolumn{6}{|c|}{ Total precipitation $(\mathbf{m m})$} & $\begin{array}{c}\text { Sum of } \\
\text { total }\end{array}$ \\
\hline 2008 & 77.5 & 9.5 & 8.4 & 46.6 & 88.6 & 230.6 \\
\hline 2009 & 16.0 & 92.3 & 129.1 & 104.6 & 26.1 & 368.1 \\
\hline 2010 & 38.5 & 134.6 & 26.6 & 100.9 & 132.4 & 433.0 \\
\hline $\begin{array}{l}1951- \\
2006\end{array}$ & 31.3 & 48.0 & 57.8 & 74.5 & 54.2 & 265.8 \\
\hline
\end{tabular}

All data were processed using the analysis of variance (ANOVA) with the SAS package (SAS Institute, 1999). The means of treatment were compared by means of Tukey's Multiple Range test and least significant difference (LSD) was declared at $\mathrm{P}<0.01$ and $\mathrm{P}<0.05$. The data were analyzed as a split-plot arrangement of a randomized complete block design with four replications. The relationship between the parameters was determined with the Pearson correlation coefficient.

\section{RESULTS}

The seed yields and yield components are shown in Table 2. A significant interaction between $\mathrm{S}$ and TS was found in the case of plant density, plant mass, the number of pods per plant and the number of seeds per plant. The lowest plant density of YL was found under NT $\left(41.5 \mathrm{~m}^{2}\right)$ and the highest in CT $\left(58.1 \mathrm{~m}^{2}\right)$. There were no significant differences between CT and RT of YL in plant density, plant mass, the number of pods and seeds per plant, but NT resulted in an increase in the number of pods (8.13) and seeds (28.3) per plant compared to the other two TS. TS did not influence the height of stems, the number of seeds per plant pod, the mass of 1000 seeds and seed yield of YL, which ranged from 1.13 (CT) to 1.18 (RT) $\mathrm{t} \mathrm{ha}^{-1}$. 
Table 2. The effect of species and soil tillage system on seed yield and yield components.

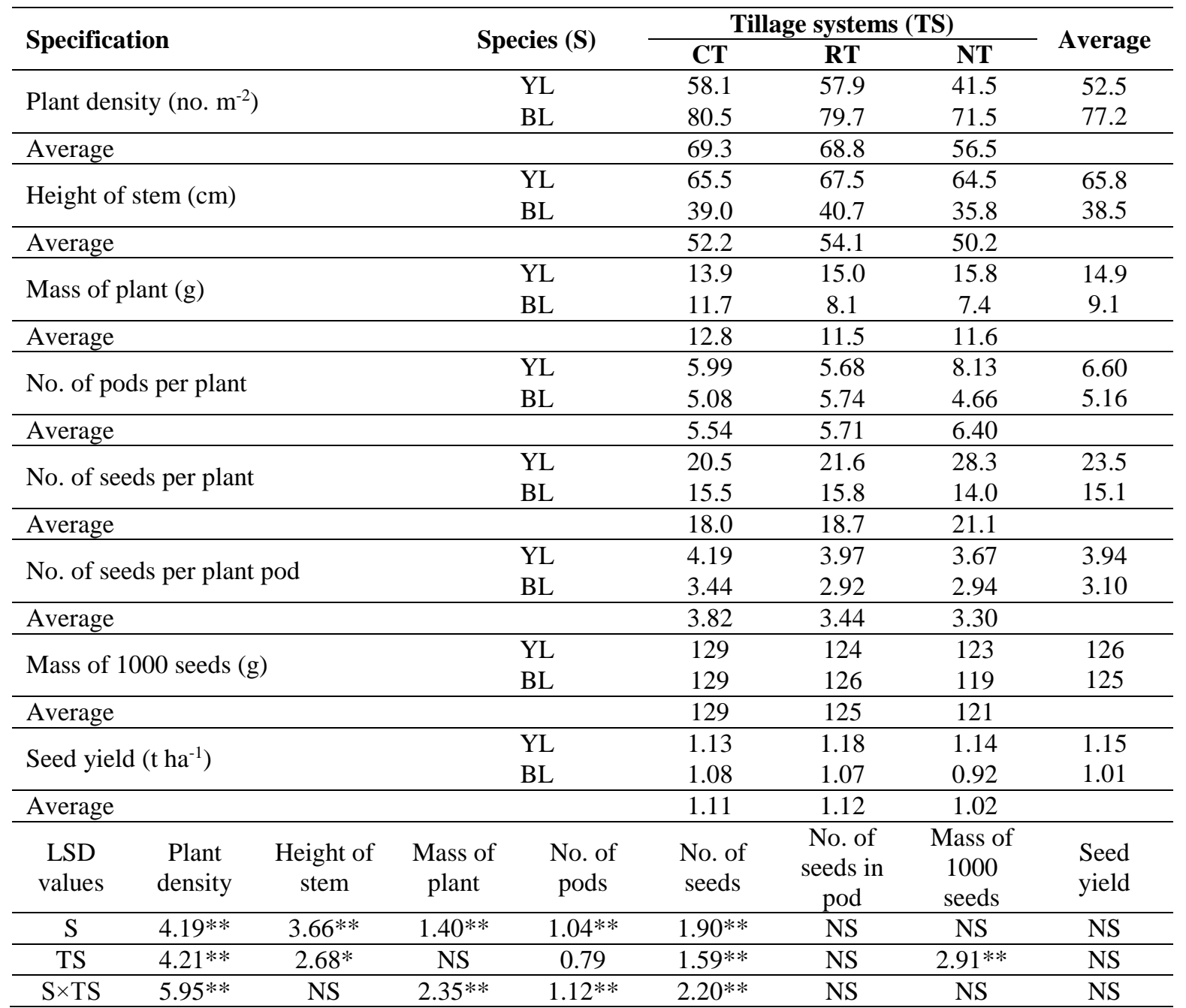

NS: not significant; ${ }^{*} \mathrm{P}<0.05$ and $* * \mathrm{P}<0.01$. Species: $\mathrm{YL}$, yellow lupin; $\mathrm{BL}$, narrow-leaved lupin. Tillage: $\mathrm{CT}$, conventional tillage; RT, reduced tillage; NT, no-tillage.

Plant density of BL in CT and in RT was similar, amounting to 80.5 and 79.7 plants per square meter, respectively. The NT caused a decrease in plant density of BL by about $12 \%$. The highest mass of BL plants was found in CT $(11.7 \mathrm{~g})$. The other yield components and seed yield were not significantly differentiated by TS. The values of seed yield in BL were very similar and ranged from 0.92 (NT) to $1.08-1.07 \mathrm{t} \mathrm{ha}^{-1}$ in CT and RT, respectively. On average, compared to BL, YL developed significantly higher stems $(65.8 \mathrm{~cm})$, a greater plant mass (14.9 g), more pods (6.60) and seeds (23.5) per plant, but the plant density in YL was lower by 25 plants per square meter. The number of seeds per plant pod and the mass of 1000 seeds were not differentiated between S. The seed yields of lupins were very similar and amounted to $1.15 \mathrm{t}$ $\mathrm{ha}^{-1}$ for YL and $1.01 \mathrm{t} \mathrm{ha}^{-1}$ for BL. On average, the highest plant density (69.3) was found in CT, while the height of stem $(54.1 \mathrm{~cm})$ was greatest in RT. NT caused a significant increase in the number of pods number per plant (6.40), the number of seeds per plant (21.1), while it resulted in a decreased plant density (56.5) and mass of 1000 seeds $(121 \mathrm{~g})$ when compared to CT and RT.

Pearson's linear correlation between the yield components and yielding of YL showed that these parameters were correlated to a varied extent (Table 3). The strongest relations, where the correlation coefficient was greater than 0.75 , were found between: the number of seeds per plant pod and seed yield under CT, the number of pods per plant and the number of seeds per plant under RT (if one of these parameters was increasing, the value of the other was growing as well). The high number of seeds per plant pod in CT and the number of seeds per plant in NT caused a reduction in the mass of 1000 seeds, because there were also strong, but negative relations between these parameters. 
Table 3. Correlation coefficients between parameters analysed for YL

\begin{tabular}{|c|c|c|c|c|c|c|c|}
\hline TS & $\begin{array}{c}\text { Parameters } \\
\text { compared }\end{array}$ & PD & NP & NS & NSP & MTS & SY \\
\hline \multirow{6}{*}{$\mathrm{CT}$} & PD & 1 & & & & & \\
\hline & NP & $-0.0478^{\mathrm{A}^{*}}$ & 1 & & & & \\
\hline & NS & $-0.4300^{\mathrm{B}}$ & $0.3611^{\mathrm{B}}$ & 1 & & & \\
\hline & NSP & $0.2360^{\mathrm{B}}$ & $-0.2252^{\mathrm{B}}$ & $-0.4695^{\mathrm{B}}$ & 1 & & \\
\hline & MTS & $-0.5527^{\mathrm{C}}$ & $0.2497^{\mathrm{B}}$ & $0.5828^{\mathrm{C}}$ & $-0.8591^{\mathrm{D}}$ & 1 & \\
\hline & SY & $0.4346^{\mathrm{B}}$ & $-0.1031^{\mathrm{A}}$ & $-0.4696^{\mathrm{B}}$ & $0.8811^{\mathrm{D}}$ & $-0.8895^{\mathrm{C}}$ & 1 \\
\hline \multirow{6}{*}{ RT } & PD & 1 & & & & & \\
\hline & NP & $-0.2617^{\mathrm{B}^{*}}$ & 1 & & & & \\
\hline & NS & $-0.0523^{\mathrm{A}}$ & $0.8186^{\mathrm{D}}$ & 1 & & & \\
\hline & NSP & $0.3000^{\mathrm{B}}$ & $-0.7244^{C}$ & $-0.2703^{\mathrm{B}}$ & 1 & & \\
\hline & MTS & $-0.1716^{\mathrm{A}}$ & $0.5942^{\mathrm{C}}$ & $0.6957^{\mathrm{C}}$ & $-0.4141^{\mathrm{B}}$ & 1 & \\
\hline & SY & $0.1661^{\mathrm{A}}$ & $0.6356^{\mathrm{C}}$ & $0.4881^{\mathrm{B}}$ & $-0.3763^{\mathrm{B}}$ & $0.1781^{\mathrm{A}}$ & 1 \\
\hline \multirow{6}{*}{ NT } & PD & 1 & & & & & \\
\hline & NP & $0.0888^{\mathrm{A}^{*}}$ & 1 & & & & \\
\hline & NS & $-0.2817^{\mathrm{B}}$ & $0.4584^{\mathrm{B}}$ & 1 & & & \\
\hline & NSP & $-0.2468^{\mathrm{B}}$ & $-0.4271^{\mathrm{B}}$ & $0.4789^{\mathrm{B}}$ & 1 & & \\
\hline & MTS & $0.4039^{\mathrm{B}}$ & $-0.5024^{\mathrm{C}}$ & $-0.7711^{\mathrm{D}}$ & $-0.0478^{\mathrm{A}}$ & 1 & \\
\hline & SY & $0.0810^{\mathrm{A}}$ & $-0.3562^{\mathrm{B}}$ & $-0.7486^{\mathrm{C}}$ & $-0.4402^{\mathrm{B}}$ & $0.5211^{\mathrm{C}}$ & 1 \\
\hline
\end{tabular}

Species: YL, yellow lupin; TS, tillage system. Tillage: CT, conventional tillage; RT, reduced tillage; NT, no-tillage. Parameters compared: PD, plant density; NP, number of pods per plant; NS, number of seeds per plant; NSP, number of seeds per plant pod; MTS, mass of 1000 seeds; SY, seed yield. *Interpretation of Pearson's linear correlation coefficient: ${ }^{\mathrm{A}} 0 \leq \mathrm{p}<0.2$ - practically no relation between characters; ${ }^{\mathrm{B}} 0.2 \leq \mathrm{p}<0.5-$ poor relation between characters; ${ }^{\mathrm{C}} 0.5 \leq \mathrm{p}<0.75$ - medium relation; ${ }^{\mathrm{D}} 0.75 \leq \mathrm{p}<0.95$ - strong relation; ${ }^{\mathrm{E}} 0.95 \leq \mathrm{p}<1.00-$ practically functional relation.

Pearson's linear correlation between the yield number of seeds per plant and seed yield. In RT, the components and yielding of BL are shown in Table 4. The strongest relations, where the correlation coefficient was greater than 0.75 , were found under CT between the number of pods per plant and the number of seeds per plant, the number of seeds per plant and the mass of 1000 seeds, the number of pods per plant and seed yield, the strongest relations were found between plant density and the number of seeds per plant, the number of pods per plant and the number of seeds per plant. Under NT the strongest relations were found between the number of pods per plant and the number of seeds per plant, the number of pods per plant and seed yield.

Table 4. Correlation coefficients between parameters analysed for BL

\begin{tabular}{|c|c|c|c|c|c|c|c|}
\hline TS & $\begin{array}{c}\text { Parameters } \\
\text { compared }\end{array}$ & PD & NP & NS & NSP & MTS & SY \\
\hline \multirow{6}{*}{ CT } & PD & 1 & & & & & \\
\hline & NP & $-0.1631^{\mathrm{A}^{*}}$ & 1 & & & & \\
\hline & NS & $-0.4028^{\mathrm{B}}$ & $0.8965^{\mathrm{D}}$ & 1 & & & \\
\hline & NSP & $-0.3235^{\mathrm{B}}$ & $-0.5260^{\mathrm{C}}$ & $-0.2242^{\mathrm{B}}$ & 1 & & \\
\hline & MTS & $-0.5301^{\mathrm{C}}$ & $0.6752^{\mathrm{C}}$ & $0.7861^{\mathrm{D}}$ & $-0.0827^{\mathrm{A}}$ & 1 & \\
\hline & SY & $0.0148^{\mathrm{A}}$ & $0.8877^{\mathrm{D}}$ & $0.7785^{\mathrm{D}}$ & $-0.6143^{\mathrm{C}}$ & $0.4874^{\mathrm{B}}$ & 1 \\
\hline \multirow{6}{*}{ RT } & PD & 1 & & & & & \\
\hline & NP & $0.7496^{\mathrm{C}^{*}}$ & 1 & & & & \\
\hline & NS & $0.7574^{\mathrm{D}}$ & $0.9694^{\mathrm{E}}$ & 1 & & & \\
\hline & NSP & $-0.0903^{\mathrm{A}}$ & $-0.4389^{\mathrm{B}}$ & $-0.2770^{\mathrm{B}}$ & 1 & & \\
\hline & MTS & $-0.3288^{\mathrm{B}}$ & $-0.0230^{\mathrm{A}}$ & $-0.0943^{\mathrm{A}}$ & $-0.6023^{C}$ & 1 & \\
\hline & SY & $0.4754^{\mathrm{B}}$ & $0.6399^{\mathrm{C}}$ & $0.7347^{\mathrm{C}}$ & $-0.2824^{\mathrm{B}}$ & $0.2681^{B}$ & 1 \\
\hline \multirow{6}{*}{ NT } & PD & 1 & & & & & \\
\hline & NP & $0.3019^{\mathrm{B}^{*}}$ & 1 & & & & \\
\hline & NS & $0.2194^{\mathrm{B}}$ & $0.9689^{\mathrm{E}}$ & 1 & & & \\
\hline & NSP & $-0.3013^{\mathrm{B}}$ & $0.3522^{\mathrm{B}}$ & $0.5375^{\mathrm{C}}$ & 1 & & \\
\hline & MTS & $-0.1139^{\mathrm{B}}$ & $0.4052^{\mathrm{B}}$ & $0.4154^{\mathrm{B}}$ & $0.4372^{\mathrm{B}}$ & 1 & \\
\hline & SY & $0.5203^{\mathrm{C}}$ & $0.7865^{\mathrm{D}}$ & $0.6932^{\mathrm{C}}$ & $0.1838^{\mathrm{A}}$ & $0.4379^{\mathrm{B}}$ & 1 \\
\hline
\end{tabular}

Species: BL, narrow-leaved lupin; TS, tillage system. Tillage: CT, conventional tillage; RT, reduced tillage; NT, no-tillage. Parameters compared: PD, plant density; NP, number of pods per plant; NS, number of seeds per plant; NSP, number of seeds per plant pod; MTS, mass of 1000 seeds; SY, seed yield. *Interpretation of Pearson's linear correlation coefficient: ${ }^{\mathrm{A}} 0 \leq \mathrm{p}<0.2-$ practically no relation between characters; ${ }^{\mathrm{B}} 0.2 \leq \mathrm{p}<0.5-$ poor relation between characters; ${ }^{\mathrm{C}} 0.5 \leq \mathrm{p}<0.75$ - medium relation; ${ }^{\mathrm{D}} 0.75 \leq \mathrm{p}<0.95$ - strong relation; ${ }^{\mathrm{E}} 0.95 \leq \mathrm{p}<1.00-$ practically functional relation 


\section{DISCUSSION}

The literature reported that NT can reduce plant density (Borin and Sartori, 1995; Blecharczyk et al., 1999; Heenan et al., 2000). In our experiment NT of YL decreased significantly the plant density, but caused an increase in the number of pods and seeds per plant. This is a normal reaction of plants. When the number of plants per square meter is lower, there are more comfortable conditions for plant development due to a lesser competition for light and nutrition. As a result, plants produce more branches, pods and seeds. A study of Clapham and Elbert-May (1989) showed that plant density had a significant effect on yield components. According to López-Bellido et al. (2000), in lupin the number of lateral branches and pods per plant are yield components most markedly affected by changes in plant density; in fact, both decrease with an increase in the number of plants per unit area (Herbert, 1977; Palta and Ludwig, 1998; Withers, 1984). With an increasing plant density, the seed number per plant pod also decreases (Herbert, 1978). In our experiment there was no significant influence of TS on seed number per plant pod, but CT and RT in the case of YL reduced the number of pods and seeds per plant, because plant density was there significantly higher than in NT. In NT, the high number of pods and seeds per plant compensated for the low plant density of YL, thus the seed yield in NT was similar to that in CT and RT. The NT also decreased plant density of BL by about $12.5 \%$ when compared to CT and RT. The losses of plant density of BL were not as high as in YL, as a result NT did not influence the number of pods and seeds per plant, while the seed yield of BL was not differentiated by TS. A similar situation was on average, the YL as a different species was sown at lower seeding rates and had a lower plant density than BL, but the number of pods and seeds per plant were higher in YL and as a result the seed yield of YL was similar to that of BL (1.15 vs. 1.01t ha-1, respectively). On average, TS did not influence seed yield of YL or BL, amounting to approx. $1 \mathrm{t} \mathrm{ha}^{-1}$. It is difficult to find the results of experiments on the effect of soil tillage systems on lupin, since most authors studied soybean. Xinhua and Mahdi (2004) found that the NT soybean seed yield was similar to those under chisel plow, moldboard plow and ridge tillage. The differences between those tillage systems were usually within $5 \%$. Also Vyn et al. (1998) observed that the differences in soybean yields between no-tillage and fall tillage treatments were, in most cases, non-significant. However, Javurek and Vach (1999) reported an $18 \%$ reduction in soybean seed yield under NT compared with CT. The results differ depending on the type of crop, soil and weather patterns (Borin and Sartori, 1995). West et al. (1996) observed poor yielding of soybean under NT when compared with other tillage systems in a corn-soybean rotation during some drought years. In turn, Heenan et al. (2000) showed that the mean annual seed yields of lupin ranged from 0.26 to $3.15 \mathrm{t} \mathrm{ha}^{-1}$ in years and differences in lupin seed yields between tillage (conventional cultivation and direct drilling) and stubble treatments over time were marginal. Those authors observed that on less stable soils it is possible for similar treatments over the same period to have a greater effect on lupin yield. In a study by Blecharczyk et al. (1999) the lowest pea yield was found under NT and also in other treatments without ploughing. The grain yields of pea were lower than under CT.

\section{CONCLUSIONS}

The seed yields of both lupin species were very similar and there were not significant differences between TS. For this reason both lupin species may be cultivated in simplified soil tillage systems without losses of seed yields.

\section{LITERATURE CITED}

Aksakal, E.L. and T. Öztaş. 2010. Changes in distribution patterns of soil penetration resistance within a silage-corn field following the use of heavy harvesting equipments. Turk. J. Agric. For. 34: 173-179.

Blecharczyk, A., G. Skrzypczak, I. Małecka and T. Piechota. 1999. Wpływ zróżnicowanej uprawy roli na właściwości fizycznej gleby oraz plonowanie pszenicy ozimej i grochu. [The effect of diverse tillage systems on physical soil properties and yielding of winter wheat and pea]. Fol. Univ. Agric. Stetin., Agric. 195(74): 171-179.

Borin, M. and L. Sartori. 1995. Barley, soybean and maize production using ridge tillage, no-tillage and conventional tillage in north-east Italy. J. Agric. Engng. Res. 62:229-236.

Borreani, G., P.G. Peiretti and E. Tabacco. 2007. Effect of harvest time on yield and pre-harvest quality of semi-leafless grain peas (Pisum sativum L.) as whole-crop forage. Field Crops Res. 100: 1-9.

Clapham, W.M. and D. Elbert-May. 1989. Influence of population on white lupin morphology and yield. Can. J. Plant Sci. 69: 161-170.

Dracup, M. and E.J.M. Kirby. 1996. Pod and seed growth and development of narrow-leafed lupin in a water limited Mediterranean-type environment. Field Crops Res. 48: 209222.

Erkovan, H.I., M. K. Gullap, K. Haliloglu and A. Koc. 2014. Substitution possibility of some biofertilizers for mineral phosphorus fertilizer in pea cultivation. Turkish Journal of Field Crops, 19(2), 175-182.

Faligowska, A., M. Selwet, K. Panasiewicz, G. Szymańska and K. Śmiatacz. 2014b. The effect of forage harvest date and inoculation on the yield and fermentation characteristics of narrow-leaved lupin (lupinus angustifolius) when ensiled as a whole crop. Legume Res. 37(6): 621-627.

Faligowska, A., Selwet M, Panasiewicz K, Szymańska G (2014a). Quality and hygienic conditions of white lupin silage, affected by forage stage of growth and use of silage additives. Turkish Journal of Field Crops 19(2), 261-266.

Gül, İ., M. Yildirim, C. Akinci, İ. Doran and H. Kiliç. 2008. Response of silage maize (Zea mays L.) to nitrogen fertilizer after different crops in a semi-arid environment. Turk. J. Agric. For. 32: 513-520.

Heenan, D.P., A.C. Taylor, K.Y. Chan, W.J. McGhie, D. Collins and W.J. Lill. 2000. The impact of long-term rotation, tillage and stubble management on lupin (Lupinus angustifolius L.) productivity. Field Crops Res. 67:11-23.

Herbert, S.J. (1978). Plant density and irrigation studies on lupins. Part 3. Seed-yield relationships of Lupinus angistifolius cv. Unicrop. N.Z. J. Agri. Res. 21: 483-489.

Herbert, S.J. 1977. Density and irrigation studies in L. albus and L. agustifolius. Ph D diss Univ of Canterbury NZ. 
Hernanz, J.L., V.S. Giron and C. Cerisola. 1995. Long-term energy use and economic evaluation of three tillage systems for cereal and legume production in central Spain. Soil Tillage Res. 35:183-198.

Javurek, M. and M. Vach. 1999. Response of soil tillage systems to yield formation of crops in short crop rotation. Fol. Univ. Agric. Stetin., Agric. 195(74): 53-58.

Jug, I., D. Jug, M. Sabo, B. Stipesevic and M. Stosic. 2011. Winter wheat yield and yield components as affected by soil tillage systems. Turk. J. Agric. For. 35: 1-7.

Kordas, L. 2005. Energy and economic effects of reduced tillage in crop rotation. Acta Sci Pol., Agric. 4(1): 51-59.

López-Bellido, L., M. Fuentes and J.E. Castillo. 2000. Growth and Yield of white lupin under Mediterranean conditions, effect of plant density. Agron. J. 92: 200-205.

Małecka, I., A. Blecharczyk, Z. Sawinska and T. Dobrzeniecki. 2012. The effect of various long-term tillage systems on soil properties and spring barley yield. Turk. J. Agric. For. 36: 217-226.

McNaughton, D. 2011. The use of lupins as an alternative to imported soya in UK livestock systems. In: Proceedings of the $13^{\text {th }}$ International Lupin Conference Poznan (Poland) 1 30 .

Palta, J.A. and C. Ludwig. 1998. Yield response of narrowleafed lupin plant to variations in pod number. Aust. J. Agric. Res. 49: 63-68.

SAS Institute. 1999. SAS/STAT user's guide. Version 7th edition. Inst Cary NC.

Vyn, T.J., G. Opoku and C.J. Swanton. 1998. Residue management and minimum tillage systems for soybean following wheat. Agron. J. 90:131-138.

West, T.D., D.R. Griffith, G.C. Steinhardt, E.J. Kladivko and S.D. Parsons. 1996. Effect of tillage and rotation on agronomic performances of corn and soybean: Twenty-years study on dark silty loam soil. J. Prod. Agric. 9:241-248.

Withers, N.J. 1984. Components of lupin yield. In Proc Int Lupin Conf. $3^{\text {rd }}$ LaRochelle France 4-8 June 1984 L'Union Natl Interprofessionelle des Proteagineux Paris p. 270-287.

Xinhua, Y., M.M. Al-Kaisi. 2004. Periodic response of soybean yields and economic returns to long term no tillage. Agron. J. 96: 723-733. 